Openings and Retrospectives

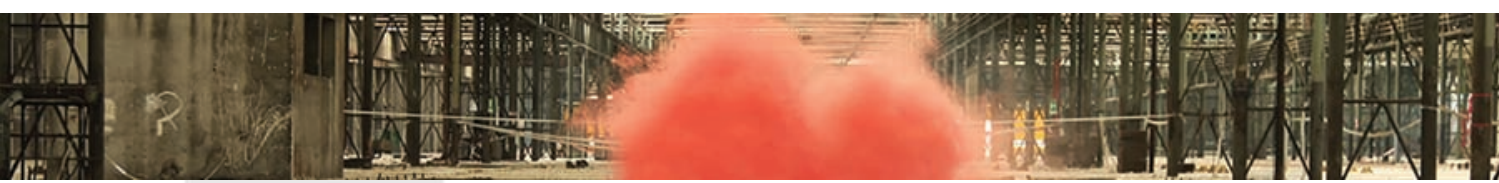

\title{
FIRES, FOGS, WINDS
}

\section{ELIZABETH A. POVINELLI}

Columbia University

(D) http: / / orcid.org/0000-0002-8119-7938

My desire is on fire. Its velocity is exhilarating. Its direction is the wind. I am simultaneously racing in front of and away from it. I am it chasing me with its inhuman legs. I want it to catch me. But I understand the consequences if it does. So I keep running just in front, but not too far away from its encroaching reach. My desire and I are asymptotic; if it becomes mine, then I am on fire. I don't know if this is a universal quality of desire, or if it is the specific condition of me.

\section{SUBJECTIFICATION}

When I was two and a half years old, we moved from Buffalo, New York to Shreveport, Louisiana, a trip less treacherous, perhaps, than the distance my paternal grandparents traveled from the vicious Austro-Hungarian and Italian Alps to the United States (see Thompson 2009). My parents burrowed our new home into the edge of an old pine forest around which slowly grew a suburb: clean, white, and affluent in the old, middle-class, white, affluent way. But dry pine 
needles beckon fire to release their intense aroma. And my brother loved fire. The drama of fire: from the first sound of the rough scratch where redhead meets sandpaper to the glorious transition of stick into flame. Under the tingling of wind in pines you can hear the sound of heat eating air, consuming it. And everything is parchment-dry in the incinerating southern summers. It can happen very quickly. Woods burn. Houses burn. Old logging factories burn. Another brother and I raced behind with water buckets and piss. And that, too, that horrid sound when water kills fire. What onomatopoeia captures its sensory disappointment? To fizzle, to fizzle out, to sputter out, to end feebly: how much better to hit the ferocious walls of rain, cold and pelting, that also consumed the north Louisiana summers, the wild thunderstorms that drove walls of water toward you, burned your skin as they ripped across it, lit trees on fire. And sometimes, when you were very, very lucky, the rain and lightning kept time with vicious little ice balls that we heard could kill you dead. We ran with fire. We ran with the rain. We were desperate to get out of the way of the fires. We were jubilant ahead of the rain, less so if we got caught by it. We wanted to experience just barely escaping death.

We also ran with the fog trucks, sometimes ahead, but often behind them. It was a game we played - who could run the longest, the closest, to the nozzle spewing the pesticides in great clouds? The trick was not to breathe. To run at full speed without breathing, then to quickly veer away from the cloud when your lungs gave out and your heart began to explode. It was great fun. We loved the sign of an approaching truck, the smell it gave off far ahead of its appearance. The love had nothing to do with how effectively the pesticide DDT rid the neighborhood of mosquitoes and their parasites. And we weren't the only ones playing with the fog. Entire generations spontaneously invented the same game across countless neighborhoods in the United States. We can ask, what were we thinking? What was anyone thinking? We can try to calculate the effects of this widespread pastime. But I will tell you something true: when I think of our races, their wild, uncontaminated intoxication is not diminished by the knowledge that they were toxic - any less than our flying ahead of raging fire is diminished by the knowledge that we could well have died, that we might be imperceptibly burning inside out from the long-lasting effects of DDT. These fires, fogs, and winds were a part of us. They were elemental to what we were because they were the elements that composed us. Yes, true, we also were juvenile accelerationists. My brothers built ancient sailing ships out of manila filing folders, toothpicks, and thread, chalking the driveway with Herodotus's lands and seas, flicking 
matches as if they were flying balls of Greek fire, but often devolving as we smeared gasoline on our sweat shirts and turned the matches on each other. This was elemental to our desire — smearing ourselves with gasoline and then racing away from the match.

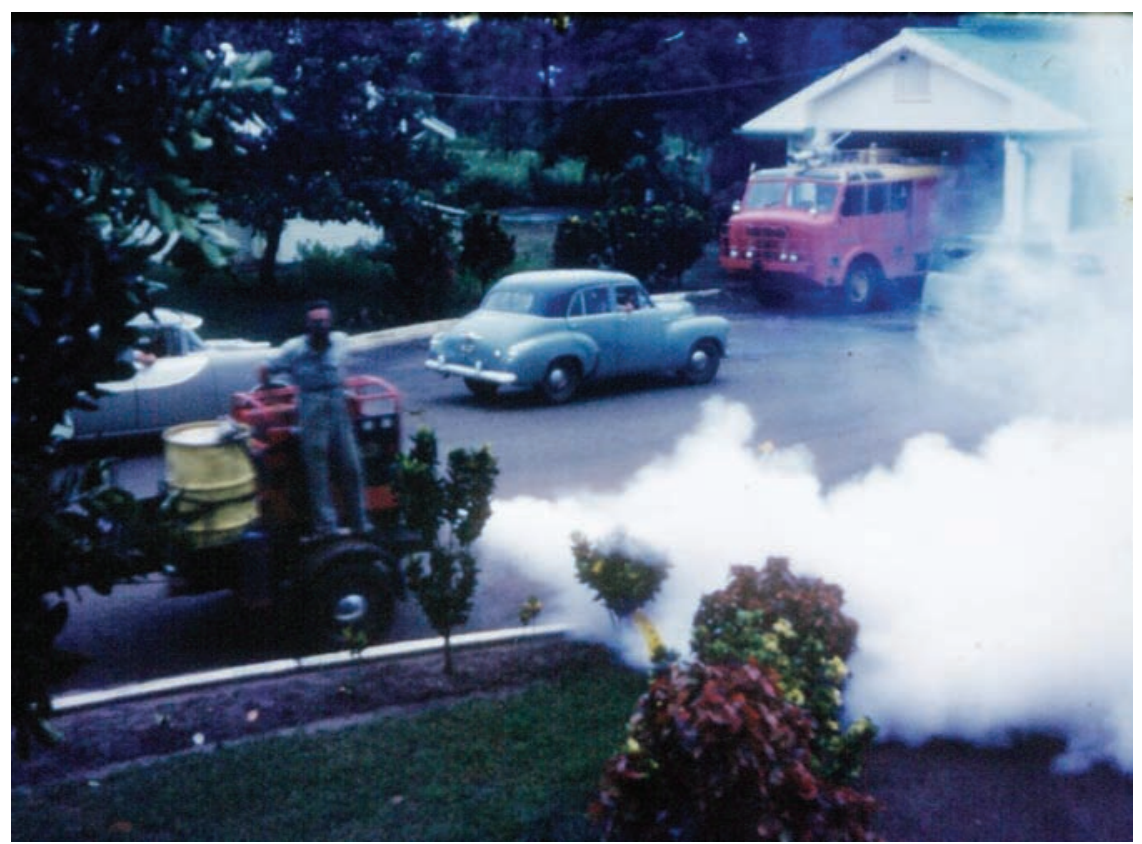

Figure 1. A fogging machine spraying the streets of Darwin, Australia, with DDT in 1962. Photo by Ken Hodge, licensed under CC BY.

The one very good thing my parents did, confronted by their wild children, was to refuse a new solution to all of this crazy shit with the neural pesticide Ritalin. Their solution to the effects of our running games was to keep us running. Burn it out of your system, they'd say. And lest we think this pure metaphor, they bought us chemistry kits and showed us how heat was expressed in chemical reactions and how heat could turn one kind of thing into another. You see fire, they said, but fire is just an expression of one form of oxidation. What's important is not what you can see, but what you can't. It's all a careful measure. It's all about knowing which chemicals are in which containers and how chemicals combine. It's probably important to wear protective clothing. Chemicals burn in ways you might not notice until it is too late. 


\section{TERRITORIALIZATION}

In Rochester, New York, the great Kodak factory is undergoing a controlled demolition and a phased reorientation. Kodak Park is becoming the Eastman Business Park. It cannot happen soon enough for the city of Rochester. The collapse of the market for film sank the Eastman Kodak Company into debt and left it to hemorrhage vast numbers of its once tens of thousands of employees, who worked across 154 buildings on 1,300 acres. In 2012, the city's unemployment topped 11.7 percent. As company and personal debt rose, tales of toxic swamps and sinkholes leaked out. Those billions of stilled memories and moving fantasies suddenly had a toxic unconscious. The material afterimages of those Kodak moments emerged as fibromyalgia, neuropathy, and primary biliary cirrhosis. Lawsuit after lawsuit followed. Kodak admitted to violations of air- and water-pollution laws that created "an underground plume of chemicals" (Hanley 1990). Cancer clusters were tracked. Superfund sites were established and managed. New forms of employment emerged as the film was run backward and a secret toxic image seen. Cleanup can be lucrative. Servpro Industries makes between $\$ 100$ and $\$ 500$ million of revenue each year by providing residential and commercial restoration and cleaning services in the United States and Canada.

Its services include water damage repair and restoration, fire damage repair and restoration, and mold remediation and restoration. The company also provides storm damage cleanup and restoration services for various disasters, such as flooding caused by heavy rains, hurricanes and tidal surges, tornados and wind damage, ice and snowstorms, and wild fires. Its cleaning services include odor removal, and sewage and biohazard cleanup, as well as services for trauma and crime scenes, and vandalism and graffiti. (S\&P Global Market Intelligence 2017)

$* * *$

Just be sure to wear protective clothing.

$* * *$

But some don't wear hazmat suits. They don't suit up, clean up, and leave. My father's sister and her family moved to Rochester when we moved to Shreveport. Wild raspberries grew in the woods behind their yard. They live and remain among the smoldering remains, not by necessity. Others remain because they have nowhere to go or no means to get there. Besides, as one man said, having 
remained on top of the toxic plume: "I don't think being on top of them will be any worse than living anywhere else" (Hanley 1990). Which does not mean that living amid the toxic plumes provides a space of composure. The invisibility of the hazard sparks an affective fire we call anxiety, which sears the neural system according to its own logics and remedies, adding velocity to system. Where are the toxins? Quasi-events and quasi-substances need trained or enhanced perception. How does one probe and discover the world that one is in, but can experience only peripherally? Artworks and digital designs are commissioned (see Shapiro 2015). How can we seal them off, if they are increasingly everywhere? New disciplines of environmental architecture are spawned. But alongside these old toxins new ones seep in, some legal, some not. How clean are the cleaners? And how corrosive the opiates of every sort, or the amphetamines that fill up the space left empty by collapsed industries (Pine 2007)? Newly timely, William Burroughs's Junky is pulled out of storage and placed in airport bookstores as the innards of shrinking cities are pulled out and sold to fuel survival economies of a growing number of impoverished families and expanding addictions. And I mean to write impoverished, not merely poor (cf. Nixon 2011). And this impoverishment has a racial form, usually African American. Detroit, Michigan; Flint, Michigan: these are the current poster children of a new American dream. Neighborhoods burn, whether from wild fires or demolition crews. And as they do, what Catherine Fennell (2015) calls “ambient envelopes" of potent neurotoxins waft across neighborhoods as houses are demolished or stripped for their copper wiring. And while Detroit might be the poster child of the toxic afterlife of collapsed industries, Syracuse, New York, less than 150 kilometers from Rochester, faces a similar problem. The city invested nearly $\$ 50$ million to build a connective corridor between Syracuse University and its boutique, deco-dotted, picturesque neighborhoods to disconnect these from the infrastructural and social rot that has settled into its interstitial spatial tissue.

Where would my parents have us run at this point? Far away is nowhere different. And the past has a specific smell. The anthropologist Ali Feser (2015) has found that in spite of the hard evidence of Kodak's liability, many former employees and their children simply could not kick their habit of associating the astringent smell of photographic chemicals with better days, happier moments, more secure futures. The sensory history of chemicals sear into the affects, creating bonds of desire, nostalgia, and mourning for the very toxins now slowly overheating bodies and landscapes. The odor embodies nostalgic sensations of full and secure employment, of a working middle class, of an intimate kinship among 
capital, production, and consumption, and of work as something other than precarious labor, underwater mortgages, and mountains of debt. Sure, it has become clear by now that profit always mattered more than the vitality of bodies; that Michel Foucault's understanding of biopolitics should have emphasized more the fact that making live was an ideological cover for letting die; that the experience of vitality and potency was more like what a meth addict feels; that the battery acid, drain cleaner, antifreeze, and Sudafed are more expertly mixed than anyone thought. Now we know that geontopower was hiding in the open, telling everyone not to worry about the great expanse of nonlife, the soils and subsoils, the aquifers and ozone, until suddenly their irradiated glow surrounded us as chemicocapital made its vicious deal with consumptive and informational capitalism (see Povinelli 2016).

$* * *$

Between the rising tides and chemical burns, our bodies are stew pots cooking up a new form of posthuman politics with new forms of posthuman corporealities.

In the French Antilles, Vanessa Agard-Jones (2014) tries to track sexuality, race, and gender expression only to find the "chemical embodiment" of coming corporealities. Transnational circuits of pesto-capital-hormone-altering pesticides like chlordecone - are simultaneously giving rise to new forms of human bodies and new forms of national political collectives. The Allied Signal Company began manufacturing chlordecone, also known as kepone, in the 1950s in Hopewell, Virginia. After an environmental spill and public scandal in the 1970s, chlordecone was banned in the United States. But powerful planter groups on Martinique and Guadeloupe (principally local whites or békés) imported stockpiles of the pesticide with the approval of France, despite the fact that France had banned its use within its continental borders. France did not outlaw its use in its overseas, racialized territories until the 1990s. The interval produced increased levels of bodily maladies (prostate cancer, for example) as well as so-called abnormalities (intersex births, for example). And these bodies-born outside the body-with-organs and confronting an anxious bionormativity-are in turn producing a politics at the material intersection of carnal vulnerability and its chemical legacy. 
Likewise, in the far north of Australia, the Karrabing Film Collective tries to tell a story that starts out with a simple premise - a group of young Indigenous men hiding in a chemically contaminated swamp after being falsely accused of stealing two cases of beer, while all around them miners are wrecking and polluting their land - and winds up in the paradox of contemporary toxic sovereignty. The young men note that they are safe within the swamp because state officials will not enter without hazmat suits. In toxic territoriality, a robust form of Indigenous sovereignty emerges. Karrabing members laugh or nod when coming to this moment in the film, most of them agreeing that what the young men say is true even as this truth has no place in sense. Or put somewhat differently, their conversation is diagnostic if not prognostic of the current condition of toxic sovereignty - a prognosis of a form of survivance in which survival does not quite fit into the picture. ${ }^{1}$ In the process, fictional representations become nonfictional analytics. In a crucial scene, three fictional police capture one of the fictional Karrabing Land Rangers at a barbed-wire fence in the middle of the bush. Karrabing have walked through, around, and over this fence collecting wild honey, shooting kangaroo and pig, or looking for various sweet fruits for their entire lives. But when the filmmakers emerged from the shooting of the scene onto a public road, two nonfictional police confronted them, asking if they had illegally entered "the contaminated region" or altered signage in the area. Suddenly Karrabing members were curious: what contaminated region? They searched the Internet and found a 2014 document submitted to the Parliamentary Standing Committee on Public Works by Australia's Department of Finance. It notes that asbestos and other highly toxic substances have been on the Cox Peninsula for more than seventy years, but never cleaned up for (because of) the largely Indigenous population in the area. Suddenly a legal but fictional sign turned into a factual but illegal sign. What was intended to produce an aesthetic experience transformed an aesthetic activity into an analytic of existence. And when the branch burns in the next fire season, a small plume of toxicity will be released as the paint boils. And with the winds might come other forms of toxicity. Although the Karrabing Film Collective does not shoot on film stock, the digital platforms on which it relies are as crucial to the overheating of that swamp and its chemical composition as the Eastman Kodak Company (see Carruth 2014).

My heart is exploding, but you are saying, “Keep running.” How do I hold my breath against the toxic winds when they have become the air? 


\section{ARISE}

Fire is the element that transforms substances. It brings about new forms with new memories, desires, and nostalgia. These forms do not abide by the logic of vitality, but manifest an affiliation with the errant harms of a grinning geontopower. Now, we know that fire is just one effect of oxidation - the loss of one or more electrons when two substances interact, a chemical bonding. The natural sciences believe that oceanic cyanobacteria were the first forms of life to produce oxygen through photosynthesis (Holland 2006). This Great Oxygenation Event set the Earth's original atmosphere off kilter, making humans the afterlife of cyanobacteria breath. Fire is merely rapid oxidation. And while water might put out some fires, it can also cause others to spark. When water meets potassium, salt, and zinc powder a flamboyant green flame ignites. But oxidation is pressing on all things, as oxygen molecules seek free radicals, slowly eating through paint and looking for an uneven distribution of lemon juice on an open-faced avocado. The brown on a cut apple, the rust on a car bumper, and the green on the Florence Baptistery relief: all are the result of different rates of oxidation, leading some people to call rust a slow fire that produces iron as ash. The difference in rates depends, in part, on the ignition temperature of a substance. If you want a fire, you need to get the substance to that temperature. Some can get there on their own. Hay mounds, pistachio nuts, and manure piles all can spontaneously combust if not stored in ways that keep their temperatures under control. Coal seams can light on fire if exposed to certain levels of oxygen. Other substances need external ignition. And if you want it to run, add an accelerant. In terms of climate change, remove more ozone and spread volatile chemicals widely. As the world overheats, the accelerant will be the winds.

In here and out there, atoms and ions, winds and rivers, attracting and repulsing each other in ways that reveal desire to be a feeble concept. Bioterrorism connects DIY hormo-terrorists with religious apocalypto-terrorists (see Preciado 2013). Free radicals refer to new alliances between post-toxic humans and kleptoelectrons. The chemistry sets have hopped out of their multicolored boxes, the chemicals remixing according to their own sense. Some bodies are running toward a new smell. Some are running away as fast as they can. 
The bonds I seek are outside me in the smell of burning pine, the memory of the madness of DDT, the touch of my various smartphones as we shoot Karrabing films to unravel the toxicity that surrounds Indigenous worlds. But thinking the nature of desire through these bonds interrupts the staid intersection of climate-change policy and science. We think there is a choice between mitigation and adaptation. But a very different kind of adaptation is already well underway. The voracious nature of information capitalism exhales its toxic winds as it redistributes an older assemblage of viruses and their hosts. The Great Climate Acceleration is underway "with faster rates of change resulting in less time for human and natural systems to adapt" (Smith et al. 2015, 333). Everything is on fire. And we are already producing our afterlife as our enjoyments seed new digital clouds and chemicals seep into more aquifers, mixing and spreading new anxieties. These fires, fogs, and winds are surrounding the poor, the black and brown, the islands, and the verging-on-extinct first. But from the future, we will have been the cyanobacteria. Who will be us is not yet clear.

\section{NOTE}

1. According to Gerald Vizenor (1999, vii), "survivance is an active sense of presence, the continuance of native stories, not a mere reaction, or a survivable name. Native survivance stories are renunciations of dominance, tragedy and victimry."

\section{REFERENCES}

Agard-Jones, Vanessa

2014 “Spray.” Somatosphere, May 27. http://somatosphere.net/2014/05/spray.html. Carruth, Allison

2014 “The Digital Cloud and the Micropolitics of Energy." Public Culture 26, no. 2: Fennell, Catherine 339-64. https://doi.org/10.1215/08992363-2392093.

2015 "Emplacement.” In "The Infrastructure Toolbox," Theorizing the Contemporary series edited by Hannah Appel, Nikhil Anand, and Akhil Gupta, Cultural Anthropology website, September 24. https://culanth.org/fieldsights/716emplacement.

Feser, Ali

2015 “It was a family': Picturing Corporate Kinship in Eastman Kodak.” Paper presented at the Visual and Cultural Studies Graduate Conference, Rochester,

Hanley, Robert N.Y., April 17.

1990 "Eastman Kodak Admits Violations of Anti-Pollution Laws." New York Times, April 6. http://www.nytimes.com/1990/04/06/nyregion/eastman-kodakHolland, Heinrich D. admits-violations-of-anti-pollution-laws.html.

2006 "The Oxygenation of the Atmosphere and Oceans." Philosophical Transactions of

Nixon, Rob the Royal Society B 361: 903-15. https://doi.org/10.1098/rstb.2006.1838.

2011 Slow Violence and the Environmentalism of the Poor. Cambridge, Mass.: Harvard University Press. 
Pine, Jason

2007 "Economy of Speed: The New Narco-Capitalism." Public Culture 19, no. 2: 35766. https://doi.org/10.1215/08992363-2006-041.

Povinelli, Elizabeth A.

2016 Geontologies: A Requiem to Late Liberalism. Durham, N.C.: Duke University Press. Preciado, Beatriz

2013 Testo Junkie: Sex, Drugs, and Biopolitics in the Pharmacopornographic Era. New York: Feminist Press.

S\&P Global Market Intelligence

2017 “Company Overview of Servpro Industries, Inc." http://www.bloomberg.com/ Shapiro, Nicholas research/stocks / private/ snapshot.asp?privcapid $=4788249$

2015 "Attuning to the Chemosphere: Domestic Formaldehyde, Bodily Reasoning, and the Chemical Sublime.” Cultural Anthropology 30, no. 3: 368-93. https:// doi.org/10.14506/ca30.3.02.

Smith, Steven J., James Edmonds, Corinne A. Hartin, Anupriya Mundra, and Katherine Calvin

2015 "Near-Term Acceleration in the Rate of Temperature Change." Nature Climate Thompson, Mark Change 5: 333-36. https://doi.org/10.1038/nclimate2552.

2009 The White War: Life and Death on the Italian Front, 1915-1919. New York: Basic Books.

Vizenor, Gerald

1999 Manifest Manners: Narratives on Postindian Survivance. Lincoln: University of Nebraska Press. 